\title{
Physiological Growth Parameters of Cotton under Mechanized and Conventional Cultivation with Varying Crop Geometry
}

\author{
M. Anbarasi* and K. Rajendran \\ Department of Agronomy, Tamil Nadu Agricultural University, \\ Coimbatore-3, Tamil Nadu, India \\ *Corresponding author
}

A B S T R A C T

K e y w o r d s
Cotton, Mechanized
cultivation,
Conventional
cultivation, Crop
geometry,
Physiological growth
parameter.

Article Info

Accepted:

07 October 2017

Available Online:

10 December 2017
A Field experiment was carried out at Eastern block, Tamil Nadu Agricultural University, Coimbatore during summer 2016 to study the effect of mechanized and conventional cultivation on physiological growth parameters of cotton under varying crop geometries. The experiment was laid out in split plot design and replicated thrice. The treatment comprised of two cultivation methods viz., mechanized cultivation $\left(\mathrm{M}_{1}\right)$ and conventional cultivation $\left(\mathrm{M}_{2}\right)$ were assigned in main plot and four spacings viz., $45 \mathrm{~cm} \mathrm{x} 15 \mathrm{~cm}\left(1,48,148\right.$ plants/ha) $\left(\mathrm{S}_{1}\right), 60 \mathrm{~cm} \mathrm{x}$ $15 \mathrm{~cm}\left(1,11,111\right.$ plants/ha) $\left(\mathrm{S}_{2}\right), 75 \mathrm{~cm} \times 15 \mathrm{~cm}\left(88,888\right.$ plants/ha) $\left(\mathrm{S}_{3}\right)$ and $75 \mathrm{~cm}$ x $30 \mathrm{~cm}\left(44,444\right.$ plants/ha) $\left(S_{4}\right)$ in sub plot. The results of this study revealed that cotton under mechanized cultivation with closer spacing of $45 \mathrm{~cm} \times 15 \mathrm{~cm}\left(\mathrm{M}_{1} \mathrm{~S}_{1}\right)$ recorded higher physiological growth parameters of leaf area index, leaf area duration and crop growth rate.

\section{Introduction}

Cotton (Gossypium hirsitum L.) the white gold is one of the most important crops throughout the history of India and it also plays an important social and economic role in the Indian society in the present age. It provides employment opportunities to about 70 million people and contributes nearly 75 per cent total raw material to the textile industry in India. Commercial cotton is grown in 80 countries and 123 countries are involved in the cotton related activities. Among 123 countries, 38 countries are the major producers and also the consuming countries, while, 30 Countries are major raw cotton exporters and 25 Countries exclusively import cotton (AICCIP, 2016). The world cotton production is 96.5 million bales of $480 \mathrm{lb}$, in which India has emerged as the world's first producer of cotton accounting 26.4 million 480 lb. bales, followed by china, United States, Pakistan etc. India also second largest consumer and exporter representing 5.3 and 5.8 million $480 \mathrm{lb}$. bales in 2015-16 (USDA, 2016). Cotton cultivation is highly labour intensive particularly for picking. In most of the developing countries, especially in India cost on labour hiring is swiftly escalating. There mechanization in cotton production will definitely play a key role by keeping the expenditure under control. High density planting system in cotton unites with mechanization by boosting the production due 
to synchronized maturity which enabled mechanized picking. Thus an attempt has been made through this study to check the influence of the mechanized and conventional cultivation method in cotton growth with high density planting.

\section{Materials and Methods}

Field experiment was conducted during summer season of 2016 at Tamil Nadu Agricultural University, Coimbatore. The experimental site is geographically located in the Western Agro Climatic Zone of Tamil Nadu at $11^{\circ} \mathrm{N}$ latitude, $77^{\circ} \mathrm{E}$ longitude with an altitude of $426.7 \mathrm{~m}$ above mean sea level. The soil of the experimental site was sandy clay loam in texture, belonging to Typic Ustropept series. The nutrient status of soil at the beginning of experiment was low in available nitrogen $(210 \mathrm{~kg} / \mathrm{ha})$, medium in available phosphorus $(12.6 \mathrm{~kg} / \mathrm{ha})$ and high in available potassium $(429 \mathrm{~kg} / \mathrm{ha})$.

The experiment was laid out in split plot design, replicated thrice. Cultivation methods were assigned to main plot and crop geometries were assigned to sub plot. Main plot treatments were two cultivation methods viz., mechanized cultivation $\left(\mathrm{M}_{1}\right)$ and conventional cultivation $\left(\mathrm{M}_{2}\right)$. Sub plot treatments were four spacings viz., $45 \mathrm{~cm} \times 15$ $\mathrm{cm}\left(\mathrm{S}_{1}\right), 60 \mathrm{~cm} \times 15 \mathrm{~cm}\left(\mathrm{~S}_{2}\right), 75 \mathrm{~cm} \mathrm{x} 15 \mathrm{~cm}$ $\left(S_{3}\right)$ and $75 \mathrm{~cm} \mathrm{x} 30 \mathrm{~cm}\left(\mathrm{~S}_{4}\right)$. For mechanized cultivation method, crop were raised in flat bed and the major cultivation practices from sowing to harvest were done with machines, whereas in conventional cultivation method, crop were raised by ridges and furrow system and the cultivation practices from sowing to harvest were done as per the crop production guide of TNAU (CPG, 2012). The machine which used for mechanized cultivation systems were, sowing with inclined plate planter, weeding with power weeder, irrigation and fertigation with micro irrigation system and harvesting with portable battery operated cotton picker. Cotton variety Surabhi was used as a test crop. The observation on physiological growth parameters viz., leaf area index (LAI), leaf area duration (LAD) and crop growth rate (CGR) were recorded. These growth indices were calculated using established formulae.

\section{Leaf area index (LAI)}

From the selected plants in each treatment plots, leaf length and maximum width of the third leaf from the top was measured from five representative samples. Total number of leaves in each plant was counted. From these observations made on 30,60, 90 and 120 DAS, the LAI was calculated using the following formula suggested by Ashley et al., (1963).

LAI $=\frac{\mathrm{L} \mathrm{x} \mathrm{W} \mathrm{x} \mathrm{N} \mathrm{x} \mathrm{K}}{\text { Land area }\left(\mathrm{cm}^{2}\right) \text { occupied by one plant }}$

Where,

$\mathrm{L}=$ Length of the leaf in $\mathrm{cm}$

$\mathrm{W}=$ Width of the leaf in $\mathrm{cm}$

$\mathrm{N}=$ Number of the leaves per plant and

$\mathrm{K}=$ Constant factor $(0.775$ for cotton $)$

\section{Leaf area duration (LAD)}

The mean LAD was calculated by using the formula suggested by Power et al., (1967), which was further modified by Kvet et al., (1971).

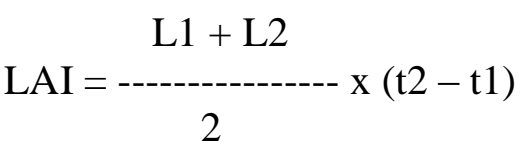

Where,

$\mathrm{L}_{1}$ and $\mathrm{L}_{2}$ are the LAI at time $\mathrm{t}_{1}$ and $\mathrm{t}_{2}$. 


\section{Crop growth rate (CGR)}

Crop Growth Rate (CGR) is defined as the rate of increase in dry weight per unit land area per unit time. The crop growth rate was estimated by adopting the formula of Watson (1958) and expressed in $\mathrm{g} / \mathrm{m}^{2} /$ day.

$\mathrm{CGR}=\frac{\mathrm{W} 2-\mathrm{W} 1}{(\mathrm{t} 2-\mathrm{t} 1)}$

Where,

$\mathrm{W}_{1}$ and $\mathrm{W}_{2}$ - dry weight of plants in $\mathrm{g}$ at times $\mathrm{t}_{1}$ and $\mathrm{t}_{2}$ respectively.

$t_{2}-t_{1}-$ time intervals in days between stages

\section{Results and Discussion}

\section{Leaf area index}

A steady increase in leaf area index (LAI) was observed from vegetative, flowering to boll formation stage. At boll development phase (120 DAS), LAI values were relatively lower as compared to other stages due to leaf senescence, physiological maturity and normal growth constraints at fag end of the crop growth stage (Table 1).

Among the cultivation methods, no significant effect was noticed on LAI at 30 DAS. But at 60, 90 and 120 DAS, higher leaf area index (2.06, 2.76 and 2.37) was noticed with mechanized cultivation $\left(\mathrm{M}_{1}\right)$ due to the continuous availability of water and nutrients which resulted in more leaf production and thus recording more leaf area index.

A similar finding reported by Dagdelen et al., (2009) is concomitant to the present result. Lower LAI was noticed with conventional cultivation $\left(\mathrm{M}_{2}\right)$. Comparing the crop geometries, higher leaf area index $(0.45,2.25$,
2.97 and 2.64 at 30, 60, 90 and 120 DAS, respectively) was observed with the spacing of $45 \mathrm{~cm} \times 15 \mathrm{~cm}\left(\mathrm{~S}_{1}\right)$ followed by spacing of $60 \mathrm{~cm} \times 15 \mathrm{~cm}\left(\mathrm{~S}_{2}\right)$ with LAI of $0.41,2.07$, 2.74 and 2.64 at 30, 60, 90 and 120 DAS, respectively due to higher plant density that might have utilized all natural resources like solar radiation, moisture, nutrients and space effectively leading to higher LAI. This is in confirmation with the earlier findings of Mohapatra (2011). In addition to this, the increase in leaf area index under closer spacings might be due to the less availability of horizontal space for individual plant, so plants has grown taller in respect to vertical space and produced more number of leaves which resulted in higher leaf area index. These results are in conformity with the findings of Sisodia and Khamparia (2007) and Shukla et al., (2013). Whereas, wider spacing of $75 \mathrm{~cm} \mathrm{x} 30 \mathrm{~cm}\left(\mathrm{~S}_{4}\right)$ registered lower LAI $(0.35,1.72,2.40$ and 2.01 at $30,60,90$ and 120 DAS, respectively).

The interaction between cultivation methods and crop geometries was significant on LAI at all the stages of observation except 30 DAS. Significantly higher LAI of 2.37, 3.12 and 2.78 at 60,90 and 120 DAS, respectively was noticed under mechanized cultivation along with $45 \mathrm{~cm} \times 15 \mathrm{~cm}$ spacing $\left(\mathrm{M}_{1} \mathrm{~S}_{1}\right)$ followed by mechanized cultivation with spacing of 60 $\mathrm{cm} \times 15 \mathrm{~cm}\left(\mathrm{M}_{1} \mathrm{~S}_{2}\right)$ which recorded 2.21, 2.92 and 2.53 at 60, 90 and 120 DAS, respectively. Lower LAI was recorded under conventional cultivation with spacing of $75 \mathrm{~cm} \times 30 \mathrm{~cm}$ $\left(\mathrm{M}_{2} \mathrm{~S}_{4}\right)$.

\section{Leaf area duration}

Significantly higher LAD (37.2, 72.3 and 77.0) was observed with mechanized cultivation of cotton $\left(\mathrm{M}_{1}\right)$ at 30-60, 60-90 and 90-120 DAS, respectively. Lower LAD was noticed under conventional cultivation of cotton $\left(\mathrm{M}_{2}\right)$ (Table 2). 
Table.1 Effect of cultivation methods and crop geometries on leaf area index of cotton

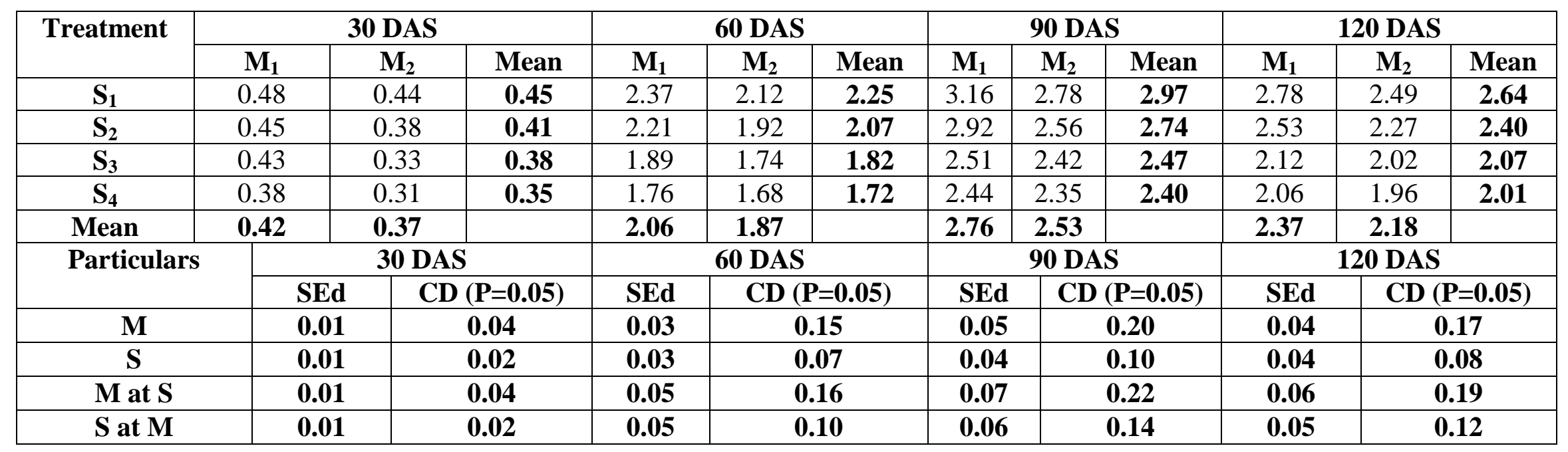

Table.2 Effect of cultivation methods and crop geometries on leaf area duration of cotton

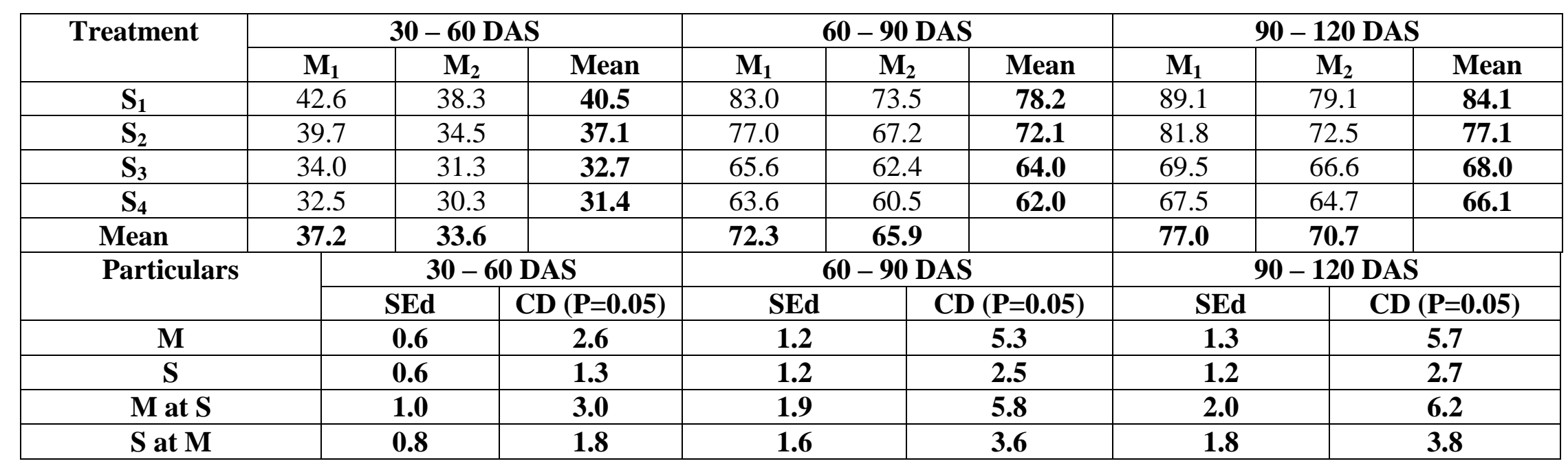


Table.3 Effect of cultivation methods and crop geometries on crop growth rate $\left(\mathrm{g} / \mathrm{m}^{2} /\right.$ day) of cotton

\begin{tabular}{|c|c|c|c|c|c|c|c|c|c|}
\hline \multirow[t]{2}{*}{ Treatment } & \multicolumn{3}{|c|}{30 - 60 DAS } & \multicolumn{3}{|c|}{60 - 90 DAS } & \multicolumn{3}{|c|}{90 - 120 DAS } \\
\hline & $\mathbf{M}_{1}$ & $\mathbf{M}_{2}$ & Mean & $\mathbf{M}_{1}$ & $\mathbf{M}_{2}$ & Mean & $\mathbf{M}_{1}$ & $\mathbf{M}_{2}$ & Mean \\
\hline $\mathbf{S}_{1}$ & 5.69 & 4.77 & 5.23 & 7.05 & 6.20 & 6.62 & 4.04 & 3.82 & 3.93 \\
\hline $\mathbf{S}_{2}$ & 4.83 & 4.20 & 4.51 & 6.52 & 5.33 & 5.93 & 3.90 & 3.41 & 3.65 \\
\hline $\mathbf{S}_{\mathbf{3}}$ & 4.34 & 4.11 & 4.23 & 5.23 & 4.67 & 4.95 & 2.78 & 2.69 & 2.73 \\
\hline $\mathbf{S}_{4}$ & 2.59 & 2.66 & 2.63 & 3.37 & 2.87 & 3.12 & 2.38 & 2.19 & 2.29 \\
\hline Mean & 4.36 & 3.93 & & 5.54 & 4.77 & & 3.28 & 3.03 & \\
\hline \multirow[t]{2}{*}{ Particulars } & \multicolumn{3}{|c|}{30 - 60 DAS } & \multicolumn{3}{|c|}{60 - 90 DAS } & \multicolumn{3}{|c|}{90 - 120 DAS } \\
\hline & \multicolumn{2}{|c|}{ SEd } & $\mathrm{CD}(\mathrm{P}=\mathbf{0 . 0 5})$ & \multicolumn{2}{|l|}{ SEd } & $\mathrm{CD}(\mathrm{P}=\mathbf{0 . 0 5})$ & SEd & \multicolumn{2}{|c|}{$\mathrm{CD}(\mathrm{P}=\mathbf{0 . 0 5})$} \\
\hline $\mathbf{M}$ & \multicolumn{2}{|c|}{0.08} & 0.33 & \multicolumn{2}{|l|}{0.10} & 0.42 & 0.06 & \multicolumn{2}{|c|}{0.25} \\
\hline $\mathbf{S}$ & \multicolumn{2}{|c|}{0.07} & 0.16 & \multicolumn{2}{|l|}{0.09} & 0.19 & 0.06 & \multicolumn{2}{|c|}{0.12} \\
\hline$M$ at $S$ & \multicolumn{2}{|c|}{0.12} & 0.36 & \multicolumn{2}{|l|}{0.15} & 0.46 & 0.09 & \multicolumn{2}{|c|}{0.27} \\
\hline$S$ at $M$ & \multicolumn{2}{|c|}{0.10} & 0.22 & 0.13 & & 0.27 & 0.08 & & .17 \\
\hline
\end{tabular}


It might be due to the fact that under mechanized cultivation, all the cultivation operations carried in time with the help of machinery which favoured the crop to utilize the growth factors and improved effectively leading to the production of more leaves compared conventional cultivation (Yadav et al., 2014).

Leaf area duration is proportional to leaf area index. Leaf area duration is also increased as leaf area index in closer spaced cotton $(45 \mathrm{~cm}$ $\mathrm{x} 15 \mathrm{~cm}$ ) than the wider spacing due to high plant density. Significantly higher leaf area duration of 40.5, 78.2 and 84.1 at 30-60, 6090 and 90-120 DAS was recorded with spacing of $45 \mathrm{~cm} \times 15 \mathrm{~cm}$. It was followed by the spacing of $60 \mathrm{~cm} \mathrm{x} 15 \mathrm{~cm}\left(\mathrm{~S}_{2}\right)$ which recorded LAD of 37.1, 72.1 and 77.1. Lower leaf area duration was observed under the wider spacings of $75 \times 30 \mathrm{~cm}\left(\mathrm{~S}_{4}\right)$ and $75 \mathrm{~cm}$ $\mathrm{x} 15 \mathrm{~cm}\left(\mathrm{~S}_{3}\right)$. Ma et al., (2007) also found higher LAD due to high plant density in maize due to more LAI at high plant density.

Interaction between cultivation methods and crop geometries significantly influenced the leaf area duration of cotton. Cotton under mechanized cultivation with closer spacings (45 $\mathrm{cm} \mathrm{x} 15 \mathrm{~cm}$ and $60 \mathrm{~cm} \times 15 \mathrm{~cm}$ ) recorded higher leaf area duration than the other combinations.

This might be due to diversion of more photo assimilates towards vegetative growth of the plant which resulted higher leaf area index and leaf area duration (Munir, 2014).

\section{Crop growth rate (CGR)}

In general, crop growth rate was less at 30-60 DAS, attained the maximum at 60-90 DAS and declined thereafter. The crop growth rate of cotton in all the stages was significantly influenced by the cultivation methods and crop geometries (Table 3).
The crop growth rate significantly differed among the cultivation methods at various stages. Significantly higher CGR (4.36, 5.54 and $3.28 \mathrm{~g} / \mathrm{m}^{2} /$ day at $30-60,60-90$ and $90-120$ DAS, respectively) was recorded with mechanized cultivation $\left(\mathrm{M}_{1}\right)$ due to corresponding increase in their plant growth and dry matter production. This result is in line with findings of Kalaichelvi (2008). The conventional cultivation $\left(\mathrm{M}_{2}\right)$ recorded lesser CGR.

Regarding crop geometries, crop growth rate was higher $\left(5.23,6.62\right.$ and $3.93 \mathrm{~g} / \mathrm{m}^{2} /$ day at 30-60, 60-90 and 90-120 DAS, respectively) in crop sown with the spacing of $45 \mathrm{~cm} \mathrm{x} 15$ $\mathrm{cm}\left(\mathrm{S}_{1}\right)$ due to higher LAI, LAD and DMP under this spacing. A similar observation of higher CGR at higher plant density was reported by Manjunatha et al., (2010) and Chukka (2012). Lower crop growth rate was recorded with spacing of $75 \mathrm{~cm} \times 30 \mathrm{~cm}\left(\mathrm{~S}_{4}\right)$.

The interaction between cultivation methods and crop geometries was significant with crop growth rate. Mechanized cultivation with the spacing of $45 \mathrm{~cm} \times 15 \mathrm{~cm}\left(\mathrm{M}_{1} \mathrm{~S}_{1}\right)$ registered significantly higher CGR (5.69, 7.05 and 4.04 $\mathrm{g} / \mathrm{m}^{2} /$ day at 30-60, 60-90 and 90-120 DAS, respectively) due to increased higher dry matter production, leaf area index and leaf area duration under this treatment combination. This was followed by mechanized cultivation with spacing of $60 \mathrm{~cm}$ x $15 \mathrm{~cm}\left(\mathrm{M}_{1} \mathrm{~S}_{2}\right)$ which recorded 4.83, 6.52 and $3.90 \mathrm{~g} / \mathrm{m}^{2} /$ day of CGR at 30-60, 60-90 and 90120 DAS, respectively. Lower CGR was recorded with conventional cultivation with the spacing of $75 \mathrm{~cm} \times 30 \mathrm{~cm}\left(\mathrm{M}_{2} \mathrm{~S}_{4}\right)$.

\section{Seed cotton yield}

Cotton under mechanized cultivation produced higher seed cotton yield of 2262 $\mathrm{kg} / \mathrm{ha}$ than the conventional cultivation method. It might be due to the mechanization 
allows a faster, less laborious and timely operations of farm tasks which claimed to lead both to increase yields and greater intensity of land use. This is in line with the findings with Yadav et al., 2014.

Among the crop geometry, closers spacing of $45 \mathrm{~cm} \times 15 \mathrm{~cm}\left(\mathrm{~S}_{1}\right)$ recorded higher seed cotton yield $(2462 \mathrm{~kg} / \mathrm{ha})$ than the others. It was comparable with the spacing of $60 \times 15$ $\mathrm{cm}\left(\mathrm{S}_{2}\right)$ recorded $2299 \mathrm{~kg} / \mathrm{ha}$ of seed cotton yield. It might be due to more number of picked bolls per unit area. This is in line with the findings Srinivasan, 2006 have obtained higher seed cotton yield with higher plant population.

Cotton under mechanized cultivation along with closer spacing of $45 \mathrm{~cm} \times 15 \mathrm{~cm}\left(\mathrm{M}_{1} \mathrm{~S}_{1}\right)$ registered higher seed cotton yield than the other treatment combination and was comparable with mechanized cultivation along with the spacing of $60 \mathrm{~cm} \mathrm{x} 15 \mathrm{~cm}$ $\left(\mathrm{M}_{1} \mathrm{~S}_{2}\right)$. Lower seed cotton yield was recorded in cotton under conventional cultivation with the spacing of $75 \mathrm{~cm} \times 30 \mathrm{~cm}\left(\mathrm{M}_{2} \mathrm{~S}_{4}\right)$.

In this experiment, it can be concluded that cotton under mechanized cultivation with crop geometry $45 \mathrm{~cm} \times 15 \mathrm{~cm}\left(\mathrm{M}_{1} \mathrm{~S}_{1}\right)$ was found to be the promising cultivation method for realizing higher growth indices and yield.

\section{References}

AICCIP. 2016. All India Coordinated Cotton Improvement Project. Annual Report, Central Institute of Cotton Research, Nagpur. pp. 1-15.

Ashley, D.A., B.D. Doss and O.L. Bennett. 1963. A method for determining leaf area in cotton. Agron. J., 55(6): 584585.

Chukka, C.R. 2012. Plant density and nitrogen effects on growth and yield of Bt cotton (Gossypium hirsutum L.).
M.Sc., Thesis, Acharya N.G. Ranga Agricultural University, Bapatla, India.

Dagdelen, N., H. Basal, E. Yilmaz, T. Gurbuz and S. Akcay. 2009. Different irrigation regimes affect cotton yield, water use efficiency and fibre quality in western Turkey. Agric. Water Manag., 96(1): 111-120.

Kvet, J., J.P. Ondok, J. Necas and P.G. Jarvis. 1971. Methods of growth analysis. In: Plant photosynthetic Production. A Manual of Methods (Eds.). Z. Seslak, J. Catsky and P.G. Jarvis. N.V. Publishers. The Hague, pp. 343- 391.

Ma, G.S., J.Q. Xue, H.D. Lue, R.H. Zhang, S.J. Tai and J.H. Ren. 2007. Effects of planting date and density on population physiological indices of summer corn (Zea mays L.) in central Shaanxi irrigation area. Chinese J. Applied Ecology, 18(6):1247-1253.

Manjunatha, M.J., A.S. Halepyati, B.G. Koppalkar and B.T. Pujari. 2010. Yield and yield components, uptake of nutrients, quality parameters and economics of $\mathrm{Bt}$ cotton genotypes as influenced by different plant densities. Karnataka J. Agric. Sci., 23(3): 423425.

Mohapatra, S.C. and S.S. Nanda. 2011. Response of various levels of nutrient and spacing in non-Bt hybrid cotton (Gossypium hirsutum L.) under rainfed situation. Res. J. Agric. Sci., 2(1): 162163.

Munir, M.K. 2014. Growth and yield response of cotton to various agronomic practices. Ph.D., Thesis, University of Agriculture, Faisalabad, Pakistan.

Power, J.F., W.O. Willis and G.A. Reichman. 1967. Effect of soil temperature, $\mathrm{P}$ and plant age on growth analysis of barley. Agron. J., 18: 459-463.

Shukla, U.N., M.S. Khakare, V.M. Bhale and S. Singh. 2013. Plant population, nutrient uptake and yield of cotton 
(Gossypium hirsutum L.) hybrids as affected by spacing and fertility levels under rainfed condition. Indian J. Agric. Res., 47(1): 83-88.

Sisodia, R.I. and S.K. Khamparia. 2007. American cotton varieties as influenced by plant densities and fertility levels under rainfed conditions. J. Cotton Res. Dev., 21(1): 35-40.

Srinivasan, G. 2006. Agronomic evaluation of Bt cotton hybrids in summer irrigated tract of southern Tamil Nadu. J. Cotton Res. Dev., 20(2): 224-225.

USDA. 2016. United States Department of Agriculture. USDA'S 92 ${ }^{\text {nd }}$ Annual
Agricultural outlook forum. Paper presented in Crystal Gateway Marriott Hotel, Arlington, Virginia. February 26, pp. 1-16.

Watson, D.J. 1958. The dependence of crop growth rate on plant dry weight. Ann. Bot., 23:37-54.

Yadav, B.S., R.P.S. Chauhan, K.N. Bhatia and N.K. Yadav. 2014. Studies on drip fertigation on growth, yield and pest incidence of American cotton (Gossyoium hirsute L) and desi cotton (Gossypium arboreum L) on sandy loam soil. $J$. Cotton. Res. Dev., 28(2): 234 -237.

\section{How to cite this article:}

Anbarasi, M. and Rajendran, K. 2017. Physiological Growth Parameters of Cotton under Mechanized and Conventional Cultivation with Varying Crop Geometry. Int.J.Curr.Microbiol.App.Sci. 6(12): 408-415. doi: https://doi.org/10.20546/ijcmas.2017.612.049 